\title{
Comparative Analysis of Exergy and Efficiency for Stratified Thermal Storage Tank with Solar Flat Plate and Evacuated Tube Collectors
}

\author{
Sukruedee Sukchai ${ }^{*}$, Yodthong Mensin and Wikarn Wansungnern \\ School of Renewable Energy Technology, Naresuan University, Thailand \\ sukruedee@hotmail.com
}

\begin{abstract}
Keywords: Exergy, Efficiency, Stratified Thermal Storage Tank, Flat Plate Collector, Evacuated Tube Collector
\end{abstract}

\begin{abstract}
In recent years, solar water heating technology has got the major importance in water heating applications. For the efficient and effective working of solar water heaters, storage of the hot water is the main issue in this water heating technologies. This paper mainly presents the exergy and efficiency comparison between the solar flat plate water heater and evacuated tube water heater. A five level stratified thermal storage tank is designed and developed for this analysis. At each level of the tank, temperature of the water is collected for each one hour interval from 9:00 to 16:00 hours in both cases and the overall exergy and efficiency of the two water heaters were calculated. The average efficiency of all the levels for flat plate and evacuated tube collectors are $7.91 \%$ and $8.20 \%$ respectively. The overall system efficiency is obtained as $39.54 \%$ for flat plate and $41.00 \%$ for evacuated tube solar collector. At each level exergy is calculate for both systems and the average exergy of all the levels for flat plate collector is $4.243 \mathrm{~kW}$ and for evacuated tube solar collector is $4.371 \mathrm{~kW}$.
\end{abstract}

\section{Introduction}

In recent years, solar water heating technology has got the major importance in water heating applications throughout the world countries. Many renewable energy systems and technologies were developed for water heating applications to reduce the fossil fuel consumption and greenhouse house gases emissions into the environment. Based on the type of solar collector, there are two main classifications of solar water heaters namely flat plate solar water heaters and evacuated tube solar water heaters [1]. Based on the area of application and the range of operating temperature solar water heaters are classified as swimming pool water heaters, built in storage type water heaters, domestic solar water heaters and large size solar water heaters for industrial and community applications [2]. There are many advantages of flat plate collectors like, both bean and diffused radiation is used, simple installation, no need of tracking and easy operation and maintenance but at high operating temperatures thermal losses are more for flat plate collectors [3]. Evacuated tube solar collectors are further classified as direct flow tubes and heat pipe tubes. To reduce and eliminate conduction and convection losses respectively, evacuated tube collectors consist of a row of parallel evacuated glass tubes [4].

From past few years, many researchers performing the research to enhance the performance of storage tanks, effective designing of solar collectors and optimizing the controller to improve the efficiency of the solar water heating systems [5]. Marco Manzan developed a model for the tank in tank storage system for solar water heaters. The system contains two tanks in which the smaller tank contains hot water and is placed in a larger tank. The larger tank is filled with buffer and heating circuit [6]. Mevlut Arslan presented a paper on Thermal performance of a vertical solar hot water storage tank with a mantle heat exchanger depending on the discharging operation parameters. This study is used to predict the performance of the vertical solar storage tank during discharging and consumption. From the results of this work it is showed that for the higher Grashof number the pre established thermal stratification is well preserved to supply the useful hot water for usage [7]. The present research paper is about the exergy and efficiency comparison between the solar flat plate water heater and the evacuated tube water heater. A stratified thermal storage tank is 
developed with five levels and the temperature is collected at each level for both the water heater systems. Efficiency and exergy of the both systems are calculated for a day from morning 9:00 A.M to 4:00 P.M with one hour interval of time.

\section{Materials and Methods}

In the experimental procedure: For the experimental procedure, a solar flat plate collector and the evacuated tube solar collectors are considered. The surface area of the flat plate collector is $2 \mathrm{~m} 2$ [8].The evacuated tube solar collector consists of 22 parallel evacuated glass tubes. A stratified thermal storage tank was developed for the storage purpose and which consists of five levels from L1 to L5. L1 is the lower level of the tank and L5 is the upper level of the storage tank. The length of each level in the stratified thermal storage tank is calculated from the equation 1 [8-9].

$$
q_{c}=\frac{h_{c} A \Delta T}{\Delta X}
$$

where,

$$
\begin{aligned}
q_{c} & =\text { rate of heat transfer, } W \\
h_{c} & =\text { convective heat transfer coefficient }, W / m \cdot K \\
A & =\text { surface area of solar collector, } m^{2} \\
\Delta T & =\text { temperature difference in the tank, }{ }^{o} K \\
\Delta X & =\text { length of each level, } m
\end{aligned}
$$

Mathematical Formulation: For the both considered solar collectors efficiency $\eta$ of the overall system is calculated with the following equation 2 .

$$
\eta=\frac{m C_{p}(\Delta T)}{A_{C} G_{t}}
$$

where,

$m=$ mass of water in the tank, $m^{3}$

$\Delta T=$ water temperature at between the top and bottom of the tank, ${ }^{\circ} \mathrm{K}$

$C p=$ specific heat capacity of water, $\frac{\mathrm{kJ}}{\mathrm{kg} \cdot \mathrm{K}}$

$A_{c}=$ surface area of solar collector, $m^{2}$

$G_{t}=$ daily solar radiation per square meter, $M J / m^{2}$

The efficiency at each level of the tank is also calculated for all the time intervals and the average efficiency of each level is also calculated. The efficiency at each level is calculated from equation (3).

$$
\eta_{j}=\frac{m_{j} C_{p}\left(T_{j-1}-T_{j}\right)}{A_{C} G_{t}}
$$

where,

$$
\begin{aligned}
& \eta j=\text { efficiency of } \mathrm{j}^{\text {th }} \text { level of the tank, } \% \\
& m j=\text { mass of water } \mathrm{j}^{\text {th }} \text { level of the tank, } m^{3} \\
& T j-1=\text { water temperature of }(\mathrm{j}-1)^{\text {th }} \text { level of the tank, }{ }^{\circ} K \\
& T j=\text { water temperature of } \mathrm{j}^{\text {th }} \text { level of the tank, }{ }^{\circ} \mathrm{K}
\end{aligned}
$$

Exergy of the both considered solar collectors was calculated from the average exergy of all the levels of the thermal storage tank. For the exergy analysis, the mass flow rate for both the collectors 
is considered as constant around $0.02 \mathrm{~kg} / \mathrm{s}$. The exergy at each level is calculated from the following equation (4). The values of $h$ and $s$ are taken from the steam tables.

$$
X_{j}=m_{j}\left[\left(h_{j}-h_{o}\right)-T_{o}\left(s_{j}-s_{o}\right)\right]
$$

Where,

$X_{j}=$ exergy of $j^{\text {th }}$ level of the tank

$m_{j}=$ mass flow rate at $j^{\text {th }}$ level of the tank

$\mathrm{h}_{\mathrm{j}} \quad=$ enthalpy of the water at $\mathrm{j}^{\text {th }}$ level of the tank

$\mathrm{h}_{0}=$ enthalpy of the water at reference or ambient temperature

$\mathrm{s}_{\mathrm{j}} \quad=$ entropy of the water at $\mathrm{j}^{\text {th }}$ level of the tank

$\mathrm{s}_{0}=$ entropy of the water at reference or ambient temperature

$\mathrm{T}_{0}=$ ambient temperature, $\mathrm{K}$

Experimental setup and data collection: The stratified thermal storage tank with 1.25 meters divided into five levels from L1 to L5 is connected to data recorder at each level. To control the flow of hot water into the storage tank is controlled by two solenoid valves. The solenoid valves are having automatic control over the temperature of the water. If the temperature of the hot water is more than $60 \mathrm{oC}$, the upper solenoid valve will be open by closing the lower solenoid valve. If the temperature is lower than the preset temperature lower valve is opened by closing upper valve. The thermal storage tank and the solenoid valve controlling mechanism are shown in figure 1 and 2 [8].

The thermal storage tank is connected to flat plate collector first and after the experiment was done with it, evacuated tube collector is connected to the thermal storage tank. The solenoid valve controlling and the mathematical formulation is same for the both solar collectors considered for this analysis. Different parameters from the environment, storage tank and from the solar collector were recorded with the help of data recorder and are mentioned in table 1.

The schematic diagram of solar collector with storage tank is shown in figure 3 [8].

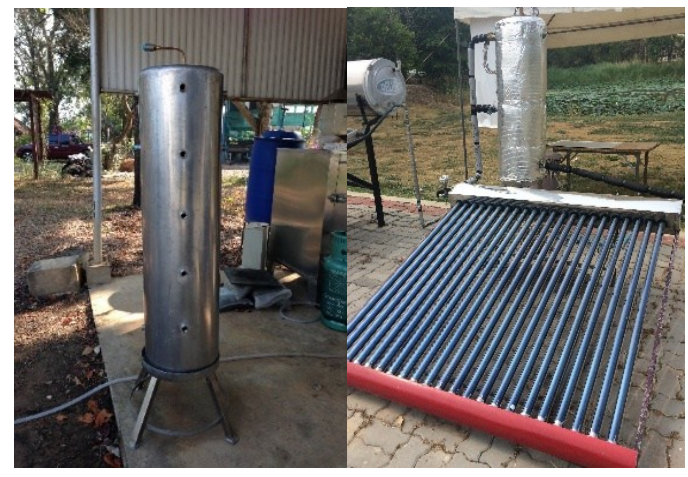

Fig. 1 Stratified thermal storage tank

Table 1 List of parameters to be recorded

\begin{tabular}{|l|l|}
\hline \multicolumn{1}{|c|}{ Positions } & \multicolumn{1}{c|}{ Parameters } \\
\hline Environment & $\mathrm{T}_{\mathrm{A}}$ (Ambient) \\
\hline & $\mathrm{S}_{1}$ (Solar radiation) \\
\hline Tank & $\mathrm{T} 5_{\text {intank }}$ (Level 5; Top) \\
\hline & $\mathrm{T} 4_{\text {intank }}$ (Level 4) \\
\hline & $\mathrm{T} 3_{\text {intank }}$ (Level 3) \\
\hline & $\mathrm{T} 2_{\text {intank }}$ (Level 2) \\
\hline Solar Collector & $\mathrm{T} 1_{\text {intank }}$ (Level 1; lower) \\
\hline & $\mathrm{T} 1_{\text {charge }}$ (water out) \\
\hline & $\mathrm{T} 2_{\text {discharge }}$ (water in) \\
\hline
\end{tabular}

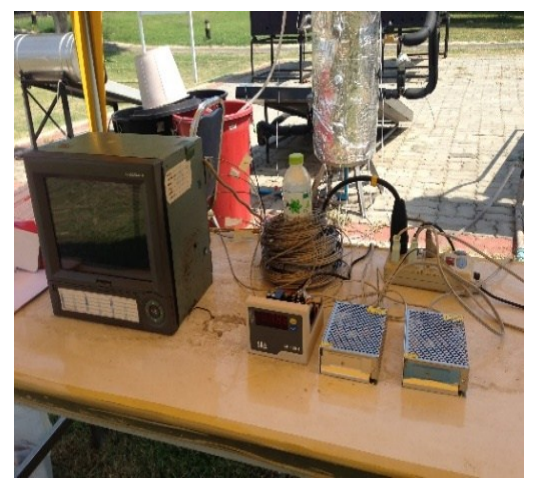

Fig. 2 Solenoid valve controlling mechanism

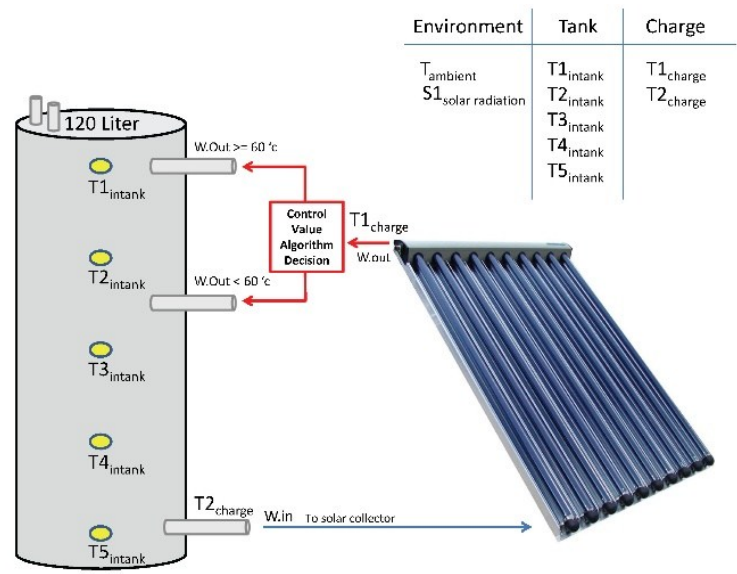

Fig. 3 Schematic view of storage tank with solar collector 


\section{Results and Discussion}

The experiment was conducted at School Renewable Energy Technology (SERT), Naresuan University, Thailand in the month of March 2016. Temperature at the all the levels of tank is collected from 9:00A.M to 4:00P.M with one hour regular intervals of time. From the obtained data, exergy and efficiency of both the solar collectors are calculated and represented in graphs as shown below.

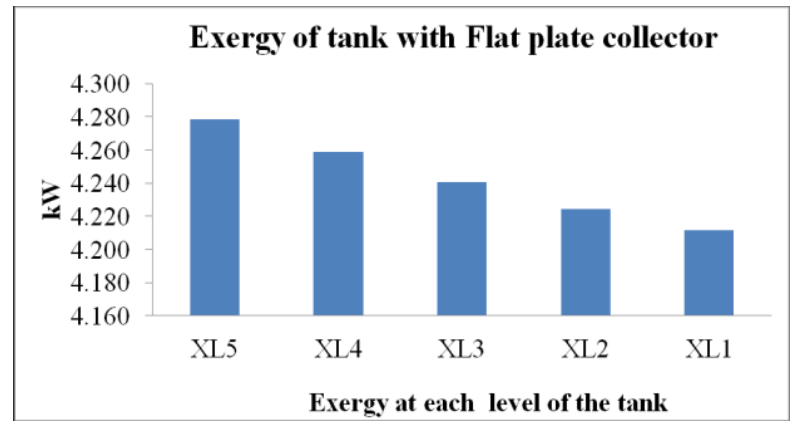

Fig 4.a Exergy of tank with Flat plate collector

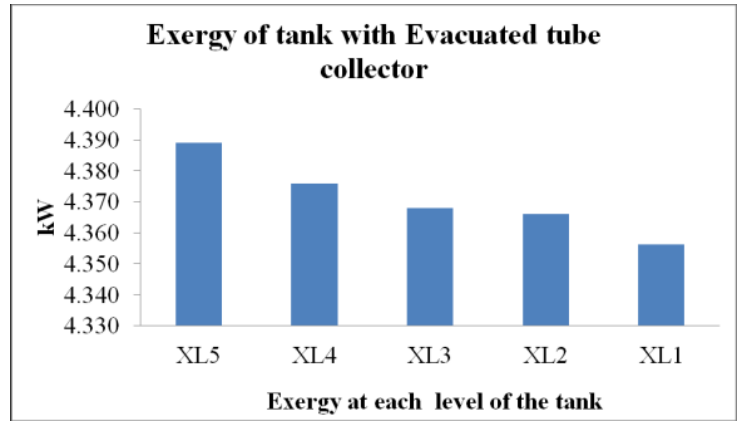

Fig 4.b Exergy of tank with evacuated tube collector

The exergy at each level of thermal storage tank for flat plate solar water heater and evacuated tube collector is mentioned in the above figure 4. Figure 4.a shows the exergy for flat plate collector and the average exergy value of the flat plate system is $4.243 \mathrm{~kW}$. Figure $4 . b$ shows the exergy for evacuated tube collector and the average exergy of evacuated tube system is $4.371 \mathrm{~kW}$.

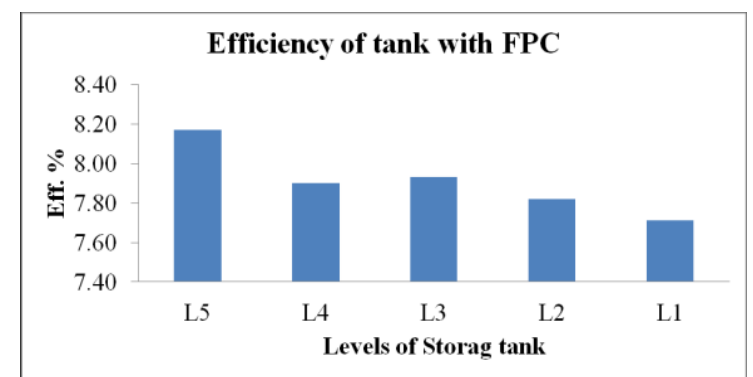

Fig 5.a Efficiency of storage tank with FPC

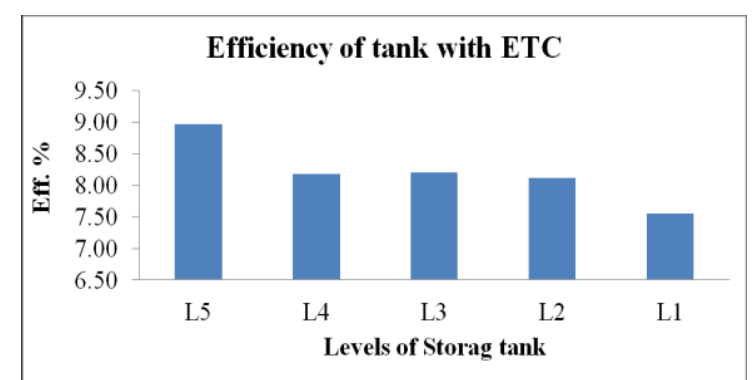

Fig 5.b Efficiency of storage tank with ETC

The efficiency of the stratified thermal storage tank is calculated and the results were shown in figure 5.a and 5.b for flat plate collector and evacuated tube collector respectively. For flat plate collector combined storage tank, the efficiencies of each level from 1 to 5 are $7.71 \%, 7.82 \%$, $7.93 \%, 7.90 \%$ and $8.17 \%$. Similarly, for evacuated tube combined storage tank the efficiencies are $7.57 \%, 8.11 \%, 8.20 \%, 8.18 \%$ and $8.96 \%$ respectively from level 1 to 5 . The overall efficiency of both the systems is calculated with the help of equation (2) with mass of the water taken as 120 liters. The flat plate collector system efficiency $39.54 \%$ and the evacuated tube collector system efficiency is $41.00 \%$ which is nearly $1 \%$ more than that of flat plate solar collector.

The exergy and efficiency of the each level of storage tank with FPC and ETC are compared separately for easy analysis in the figure 6.a and 6.b.

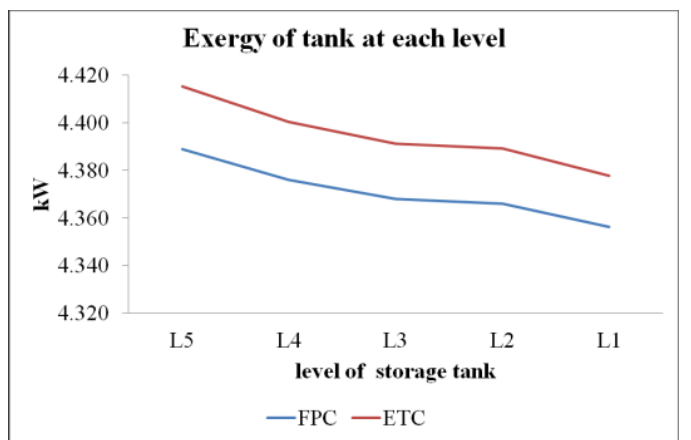

Fig 6.a Exergy of storage tank with FPC and ETC at each level

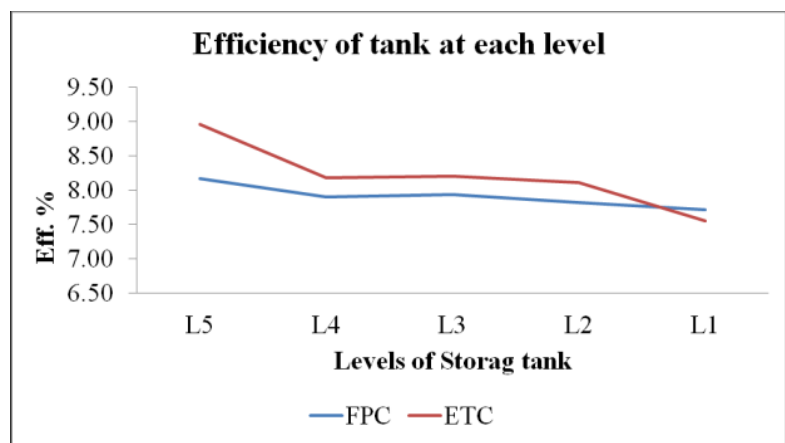

Fig 6.b Efficiency of storage tank with FPC and ETC at each level 
The average exergy and efficiency of tank from all the levels are $4.243 \mathrm{~kW}$ and $7.91 \%$ respectively for the stratified thermal storage tank with flat plate solar collector and with evacuated tube solar collector the average exergy and efficiency of the storage tank for all the levels are $4.371 \mathrm{~kW}$ and $8.20 \%$ respectively.

\section{Conclusion}

The present paper discussed about the main solar water heating technologies like flat plate and evacuated tube solar water heaters with stratified thermal storage tank. Design considerations, required parameters for the data collection, Mathematical formulation to calculate the exergy and efficiency of the both water heaters and the control flow chart of the solenoid valve are mentioned. The average exergy and efficiency of the storage tank combined with flat plate collector are $4.243 \mathrm{~kW}$ and $7.91 \%$ respectively and with evacuated tube collector are $4.371 \mathrm{~kW}$ and $8.20 \%$ respectively. The efficiencies at each level of the tank from 1 to 5 with flat plate collector are $7.71 \%, 7.82 \%, 7.93 \%, 7.90 \%$ and $8.17 \%$. Efficiencies for levels 1 to 5 of stratified thermal storage tank with evacuated tube collector are $7.57 \%, 8.11 \%, 8.20 \%, 8.18 \%$ and $8.96 \%$ respectively. The overall efficiency of solar flat plate collector combined thermal storage tank is $39.54 \%$ and solar evacuated tube collector combined thermal energy tank efficiency is $41.00 \%$. From the results it is concluded that, stratified thermal storage tank with evacuated tube collector is having more efficiency and the performance of this system is more effective than that of storage tank with flat plate collector.

\section{Acknowledgement}

The researchers would like to thank to Naresuan University for the financial support and School of Renewable Energy Technology (SERT), Naresuan University providing assistance during the research.

\section{References}

[1] Tiwari, G. and s. Suneja, Solar Thermal Engineering Systems. 1997, New Delhi: Narosa Publishing House

[2] Garg, H.P. and J. Prakash, Solar energy : fundamentals and applications. 2000: New Delhi: Tata McGraw-Hill Publishing, c2000.

[3] Weiss, W., Process Heat Collectors: State of the Art Within Task 33/IV; IEA SHC-Task 33 and SolarPACES-Task IV: Solar Heat for Industrial Processes. 2008: AEE INTEC.

[4] Kumar, R., et al., Thermal performance of a solar pressure cooker based on evacuated tube solar collector. Applied Thermal Engineering, 2001. 21(16): p. 1699-1706.

[5] Li, S., et al., Study on Performance of Storage Tanks in Solar Water Heater System in Charge and Discharge Progress. Energy Procedia, 2014. 48: p. 384-393.

[6] Padovan, R., et al., Model Development and Validation for a Tank in Tank Water Thermal Storage for Domestic Application. Energy Procedia, 2015. 81: p. 74-81.

[7] Arslan, M. and A.A. Igci, Thermal performance of a vertical solar hot water storage tank with a mantle heat exchanger depending on the discharging operation parameters. Solar Energy, 2015. 116: p. 184-204.

[8] Sukruedee Sukchai, Y.M., Tawat Suriwong, Wikran Wangsungnern, Energy and exergy analysis of stratified thermal storage tank combine with solar flat plate collector.

[9] Saranyanit, S., heat transfer, T.P.A.T.-. Japan), Editor. 2002: Bangkok. 